\title{
PREVENTION OF RADICALISM FOR ALPHA GENERATIONS IN RAUDHATUL ATHFAL BY FATAYAT NU CILACAP CENTRAL JAVA
}

\author{
Novan Ardy Wiyani \\ Islamic State Institute of Purwokerto \\ email: fenomenajiwa@gmail.com
}

\begin{abstract}
This research is qualitative research aimed at describing the prevention of radicalism in alpha generation in Raudhatul Athfal (RA) by activists of Fatayat NU, Cilacap district. Radicalism is one of the threats to the millennial generation, including the generation of alpha, namely those who are studying at the level of early childhood education such as Raudhatul Athfal (RA). From the results of the study, it was revealed that radicalism had plagued teachers at Raudhatul Athfal (RA) and had an influence on the radical understanding of alpha generation in early childhood education. This was responded to by the Fatayat NU activist in Cilacap district who became a teacher at Raudhatul Athfal (RA) by making efforts to prevent radical understanding through seven ways. First, assist teachers who are influenced by radical understanding through non-formal discussion activities in a family atmosphere. Second, fortify themselves from the negative influence of radicalism by continuing to increase knowledge and religious insights from the perspective of ahlussunnah wal jamaah. Third, optimizing the implementation of religious education for the alpha generation. Fourth, optimizing the implementation of character education for the alpha generation. Fifth, introduce nationalism to the alpha generation. Sixth, creating a Raudhatul Athfal (RA) environment and a child-friendly family environment. Seventh, selective on learning materials and learning media to make sure that the learning materials and media do not have the potential to bring radical understanding.
\end{abstract}

Keywords: radical, Raudhatul Athfal, fatayat. 
الملخص: هذا البحث يهدف إلى وصف طريقات وقاية الأجيال من التشدد في الدين في

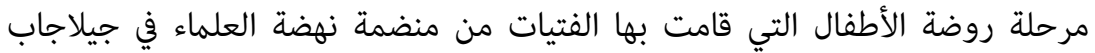
(pacaliC)

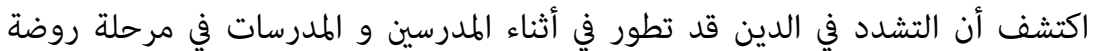

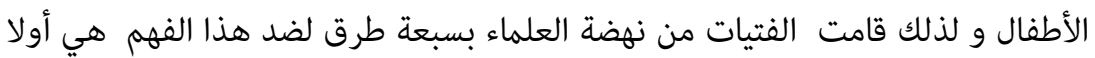

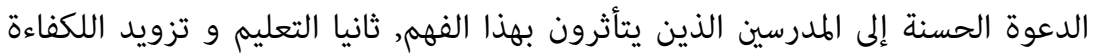

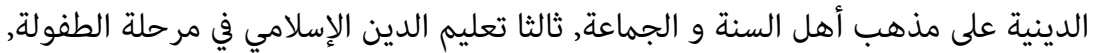
رابعا تأديب الأخلاق إلى الأجيال في مرحلة الطفولة الطالة, خامسا إحياء القومية إلى الأجيال في

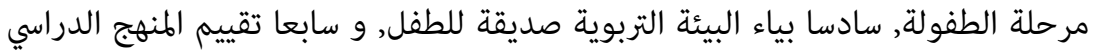
و تنظيفه من الفهم التشددي.

Abstrak: Penelitian ini merupakan penelitian kualitatif yang ditujukan untuk mendeskripsikan pencegahan radikalisme pada generasi alpha di Raudhatul Athfal (RA) oleh aktivis Fatayat NU kabupaten Cilacap. Radikalisme menjadi salah satu ancaman bagi generasi millenial, termasuk generasi alpha, yaitu mereka yang sedang belajar di jenjang pendidikan anak usia dini seperti pada Raudhatul Athfal (RA). Dari hasil penelitian terungkap bahwa radikalisme sudah mewabah pada guru di Raudhatul Athfal (RA) dan berpengaruh pada penanaman paham radikal bagi generasi alpha di jenjang pendidikan anak usia dini. Hal itu direspon oleh aktivis Fatayat NU kabupaten Cilacap yang menjadi guru di Raudhatul Athfal (RA) dengan melakukan upaya pencegahan terhadap paham radikal melalui tujuh cara. Pertama, melakukan pendampingan kepada para guru yang terpengaruh paham radikal melalui kegiatan diskusi secara nonformal dalam suasana yang penuh kekeluargaan. Kedua, membentengi diri dari pengaruh negatif radikalisme dengan terus meningkatkan pengetahuan dan wawasan keagamaan dalam perspektif ahlussunnah wal jamaah. Ketiga, mengoptimalkan pelaksanaan pendidikan agama bagi generasi alpha. Keempat, mengoptimalkan pelaksanaan pendidikan karakter bagi generasi alpha. Kelima, mengenalkan paham nasionalisme pada generasi alpha. Keenam, menciptakan lingkungan Raudhatul Athfal (RA) dan lingkungan keluarga yang ramah anak. Ketujuh, selektif terhadap materi-materi pembelajaran dan media pembelajaran 
untuk memastikan bahwa materi-materi pembelajaran dan media pembelajaran tidak berpotensi memunculkan paham radikal.

\section{INTRODUCTION}

Religious radicalism, including Islamic radicalism in the millennial era, is now increasingly widely discussed by all groups. Of course, the conversation appears not without cause. Islamic radicalism is suspected to be one of the causes of the emergence of acts of terrorism in Indonesia. These acts of terrorism emerged against the background of the motives of jihad, motives for revenge, and motives of dislike due to differences in ethnicity, religion, race, and customs.

Of course, the issue of Islamic radicalism should not be allowed considering the effect of the rolling snowball is so large and dangerous. Various efforts were also made by the government and related parties including Islamic religious institutions or organizations in Indonesia, one of which was Fatayat NU as an Islamic religious organization that was used as a forum for women from the Nahdhatul Ulama (NU).

At present in Indonesia and the world, NU is known as a moderate and pluralist Islamic religious organization. The attitude of moderate and pluralist activists makes them become Muslims who are tolerant and reject radicalism in the teachings of Islam. ${ }^{1}$

Zuly Qodir in his research revealed that radicalism must be considered by many parties, such as the government, law enforcement officials, community leaders, community activists, teachers and all levels of society. When radicalism escapes the attention of these parties, what happens is that terrorism will be born, in which terrorism is not following the teachings of Islam which are rahmahmatan lil alamin. $^{2}$

Speaking of Islamic radicalism is also speaking about crossgeneration in Islamic radicalism. Islamic radicalism has existed since the old order era, and now in the millennial era, Islamic radicalism has emerged with a different generation of radical Islam. The generation

Alexander R Arifianto, "Practicing What It Preaches? Understanding the Contradictions between Pluralist Theology and Religious Intolerance within Indonesia's Nahdlatul Ulama," Al-Jami'ah: Journal of Islamic Studies 55, no. 2 (15 December 2017): 241-64, https://doi.org/10.14421/ajis.2017.552.241-264.

Zuly Qodir, "Kaum Muda, Intolerance, dan Radikalisme Agama," Jurnal Studi Pemuda 5, no. 1 (9 Agustus 2018): 429, https://doi.org/10.22146/ studipemudaugm.37127. 
of radical Islam in the old order was more influenced by changes that occurred in the country, the movement also existed on a national scale. That is the reason for the end of their movement to establish the Indonesian Islamic State.

Whereas the generation of radical Islam in the millennial era was more influenced by changes that occurred in all corners of the world, then the movement was trans-national. That is the reason for the end of their movement to establish the Islamic Caliphate.

The generation of radical Islam in the millennial era spread Islamic radicalism, one of which was through the use of Information and Communication Technology (ICT). They spread and instill radical Islamic doctrine to millennial generations, especially those who are the digital immigrant generation and generation $\mathrm{Y}$ and $\mathrm{Z}$. Digital immigrant generations are those who have known and used ICT equipment since they were adults. Then generation $\mathrm{Y}$ were those who lived in the millennial era with births from 1981 to 1994. While generation $Z$ were those who lived in the millennial era with a birth span of 1995 to 2010. Generation Y and generation Z of their lives were greatly influenced by computers, laptops, gadgets, and the internet. They not only exist in the real world but also exist in cyberspace, they can even exist more in cyberspace than in the real world. $\mathrm{Y}$ and $\mathrm{Z}$ generations spend more time on social networks, such as Facebook, Instagram, and Twitter. ${ }^{3}$

There are interesting findings from the results of research at the Center for Cultural and Social Change Studies (PSBPS) of the Muhammadiyah University of Surakarta (UMS). Researchers at PSBPS UMS revealed that Facebook is still a potential media to spread radicalism. The findings were obtained after PSBPS UMS researched in the period from September to November 2017. Facebook remains the dominant one compared to the other two social networking platforms that have the potential to become a media for disseminating radical ideas. Then Instagram became a social network that was more dominantly used to spread radical understanding in generation $\mathrm{Z}$ when compared to Facebook. ${ }^{4}$

3 Mona Ratuliu, Digital Parenting: Tips Mengasuh Kids Zaman Now (Jakarta: Mizan Publika, 2018), 5.

4 Andrian Pratama Taher dan Baca selengkapnya di artikel "Facebook Masih Jadi Lahan Penyebar Paham Radikalisme di Indonesia “, https://tirto.id/cA9w, 
After successfully sowing and planting radical seeds, a generation of millennial radical Islam may sow and plant radical seeds in the next generation, namely alpha generation. Alpha generation is those who live in the millennial era with a birth year range from 2011 to 2035. ${ }^{5}$ They are also called the generation of digital natives. This is because they know and can use ICT equipment from an early age. They are children who are studying at the level of Early Childhood Education.

There is one case that shows that radical understanding has entered the PAUD level. This case happened in Banyumas district, Central Java province. The final verse of the song (Tepuk Anak Soleh), which is the phrase (Kafir No) which is usually sung by preschoolers and kindergarten (TK) in Banyumas, Central Java, triggers a polemic. Khasanatul Mufidah (chairman of HIMPAUDI Banyumas), revealed that he received a complaint from a student $>$ g guardian that his child no longer wanted to be friends with children of different religions. The guardian said that his son>s attitude was triggered by a song ending in (Islam Yes, Kafir No) on the song (Tepuk Anak Soleh). ${ }^{6}$ The case has led to an intolerant attitude which is one of the radical views of Islam towards other religious people.

Intolerance if left unchecked, in turn, can bring forth the seeds of terrorism and this certainly should not be allowed to happen. ${ }^{7}$ Preventive efforts (prevention) against radical understanding from an early age must be done optimally by all parties. One of the parties who was moved to carry out such preventive efforts was Fatayat NU, Cilacap district. Based on the results of an interview with one of the Fatayat NU administrators in Cilacap district, initial findings were obtained that prevention of radical understanding in the generation of alpha was carried out by them in PAUD institutions. This is

"Facebook Masih Jadi Lahan Penyebar Paham Radikalisme di Indonesia Baca selengkapnya di artikel "Facebook Masih Jadi Lahan Penyebar Paham Radikalisme di Indonesia “, https://tirto.id/cA9w,” id, 4 Desember 2017, https://tirto.id/facebookmasih-jadi-lahan-penyebar-paham-radikalisme-di-indonesia-cA9w.

5 J. Sumardianta dan Wahyu Kris AW, Mendidik Generasi $Z$ dan A: Marwah Era Millenial Tuah Generasi Digital, (Jakarta: Grasindo, 2018), 35.

6 Muhammad Ridlo, “Sepotong Lirik Lagu 'Tepuk Anak Soleh' Picu Polemik di Banyumas," accessed on 22 Juni 2019, https://www.liputan6.com/regional/ $\mathrm{read} / 3045091 /$ sepotong-lirik-lagu-tepuk-anak-soleh-picu-polemik-di-banyumas.

7 Bagus Takwin, et.al, Studi tentang Toleransi dan Radikalisme di Indonesia: Pembelajaran dari 4 Daerah Tasikmalaya, Jogjakarta, Bojonegoro, dan Kupang, 2018 ed., vol. 2018 (Jakarta: INFID, 2018), 1. 
because many members of the Fatayat NU Cilacap district are active as teachers in early childhood education institutions like Raudhatul Athfal (RA).

That is what later made the authors interested in conducting research aimed at getting a description of the prevention of radical understanding for the generation of alpha in Raudhatul Athfal (RA) by activist Fatayat NU, Cilacap district, Central Java province. The description can be used as a guide for early childhood institutions that want to develop a moderation program for early childhood.

To achieve the above research objectives, the authors use a qualitative approach in this study. While the type of research used is phenomenology. The data in this study were collected by interview, observation and documentation techniques. To produce credible data triangulation techniques used data sources, namely by bringing together data sourced from three sources. Then the data were analyzed using the Miles and Huberman model of data analysis techniques which included data reduction, data presentation, and data verification.

\section{CHARACTERISTICS OF RELIGION IN ALPHA GENERATIONS}

In the millennial era, alpha generation is a digitally native generation that already knows and uses ICT equipment, especially gadgets. They are a generation born in the range of 2011 to 2035. In 2019 they are now at the age of 0 to 8 years. If referring to NAEYC (National Association for Education of Young Children), then children aged 0 to 8 years fall into the category of early childhood. ${ }^{8}$

But if referring to the Republic of Indonesia Law Number 20 of 2003 concerning the National Education System, it can be seen that the category of early childhood is those who are aged 0 to 6 years. They study in PAUD institutions both formal and non-formal, such as the Child Care Center (TPA), Play Group (KB), Kindergarten (TK), and Raudhatul Athfal (RA). ${ }^{9}$ The development of early childhood is optimized through the implementation of PAUD services in PAUD

$8 \quad$ Siti Aisyah, et.al, Perkembangan dan Konsep Dasar Pengembangan Anak Usia Dini (Jakarta: Universitas Terbuka, 2012), 1.3.

9 Suyadi and Maulidya Ulfah, Konsep Dasar PAUD (Bandung: Rosda, 2013), 13. 
institutions by PAUD teachers. Optimized development aspects include religious and moral, social-emotional, cognitive, linguistic, and physical-motoric aspects.

Religious and moral aspects are the first and foremost aspects developed by PAUD teachers. The development of religious and moral aspects in early childhood which they are the generation of alpha is closely related to the development of religion in the alpha generation.

Religious development in children aged 0 to 3 years is still difficult to see. Some argue that the signs of religion in them grow integrally and are intertwined with other psychological functions. ${ }^{10}$ Meanwhile, the development of religion in children aged 3 to 6 years is at the stage of the fairy tale stage or fairy tale level. At this level, the concept of knowing God in children is more influenced by fantasy and emotions. This is because life at this time is still much influenced by fantasy life so that in responding to religion any child still uses a fantastic concept that is filled with tales or stories. At the age of 3 to 6 years, children live the concept of the Godhead according to the level of intellectual development. ${ }^{11}$

Intellectual development in children aged 3 to 6 years refers to changes in the thinking process. If you refer to the theory of cognitive development according to Jean Piaget, then they are in the preoperational stage. At this stage, symbolic thinking and language begin to be seen to describe objects and events, but children>s thinking is not logical and does not resemble the way adults think. ${ }^{12}$

Based on the theory of the development of religion at the stage of the fairy tale stage and the theory of cognitive development at the pre-operational stage, three religious characteristics can be concluded in the alpha generation. First, the child understands his religion by listening to stories or tales delivered by adults to her/him. In Islam, for example, stories about the Prophet and Prophet, stories about the Companions of the Prophet, stories about Wali Songo, and so forth.

This first characteristic makes the teacher develop the religious and moral aspects of them by using storytelling and storytelling

\footnotetext{
${ }^{10}$ Jalaluddin, Psikologi Agama (Jakarta: Rajawali Press, 2015), 57.

${ }^{11}$ Jalaluddin, Psikologi Agama (Jakarta: Rajawali Press, 2015), 58.

${ }^{12}$ Rini Hildayani, et.al, Psikologi Perkembangan Anak (Jakarta: Universitas Terbuka, 2013), 6.10.
} 
methods. The stories or tales delivered by the teacher make children fantasize. They think and try to describe the various figures and behaviors of each figure discussed by the teacher. They are very fond of miracles and miracles that are presented in a story or a fairy tale. In the current millennial era, teachers can use videos that can be downloaded from YouTube as a medium to convey a story or a fairy tale for alpha generation.

Second, children understand their religion with the symbols used by religion. These symbols can be places, clothes, names, special activities, and others. Thus generation alpha can understand its religion by recognizing its place of worship, clothes used to carry out its worship, names that can show oness religion, religious activities, and so on.

For example, Muslim children understand their religion by recognizing mosques as places of worship (prayer), recognizing prayer as a form of worship, getting to know various prayers, knowing mukenah as clothes for prayer for women, knowing peci, koko clothes and sarongs as prayers. The second characteristic makes teachers develop religious and moral aspects of them using observation methods and media images and animated video media that contain religious content or material as well.

Third, children understand their religion with language activities. Language activities include listening, speaking, reading and writing. The four language activities are also used in religious life. In Islam, for example, listening activities are carried out when listening to the verses of the Quran which are read by someone. In speaking activities, a Muslim expresses certain sentences in certain situations or conditions, such as saying (thank God) when getting a pleasure. Thus the generation of alpha can understand its religion by listening to the recitation of the Qur>an, reading and writing the Qur>an, and by saying the sentence thayyibah. This makes teachers develop religious and moral aspects in children by using the method of reading aloud and playing roles.

The optimal development of religion in children will influence children>s moral development. Optimization of religious development in children is done through the care done by parents and other adults. John W. Santrock revealed that positive care can make children aware of their obligations, including their obligations to worship. Positive 
parenting from parents and other adults, including teachers can also make children have reasoning for good and bad deeds. ${ }^{13}$ But of course, not all parents, including teachers, can provide positive care. Whether it is realized or not the model of care given by parents and teachers to children is not only strongly influenced by their educational and socio-economic backgrounds, but also by their religious views. Religious views on parents and teachers who are narrow and contain radicalism will be able to bring up the symptoms of radicalism in religion in children. This is where then the detection of the symptoms of radicalism in religion in children can be seen from the views and religious behavior of parents and teachers.

\section{THE ROLE OF FATAYAT NU ACTIVISTS IN PREVENTING RADICALISM FOR ALPHA GENERATION IN RAUDHATUL ATHFAL (RA) CILACAP REGENCY}

Fatayat NU is an autonomous organization Nahdhatul Ulama (NU) which aims to form young Islamic women who are devoted to Allah Swt., virtuous, charitable, capable, and responsible and useful for religion and the country. Besides, Fatayat NU also aims to realize a sense of loyalty to the principles, aqeedah, and the aim of NU in upholding Islamic law and creating a just and prosperous society that is evenly distributed and blessed by Allah Swt. To realize this goal, various efforts have been made, one of which is to increase the role of Indonesian women in all areas of religious, state and community life.

Fatayat NU is growing so rapidly and reaches all provinces and districts in Indonesia, including in the Cilacap district of Central Java province. As of January 1, 2019, as many as 236 Fatayat NU branch leaders in Cilacap District have been formed from a total of 284 existing villages.

Based on the results of data collection from Fatayat NU activists in Cilacap district, it can be seen that several things motivate them to be actively involved in Fatayat NU. First, Fatayat NU is a forum to develop itself for young NU women as an effort to preserve the ideology of ahlussunah wal jamaah an nahdliyah. Second, Fatayat NU can be used as a forum to increase the role of Indonesian women in all areas of religious, national and community life. Third, Fatayat NU

13 John W. Santrock, Masa Perkembangan Anak (Jakarta: Salemba Humanika, 2011), 94 . 
can be used as a medium to become a quality young generation from all aspects, without leaving its nature as a woman. Fourth, Fatayat $\mathrm{NU}$ can be a media to find out more about Islamic values and can be used as a forum for women to be involved in positive community activities. Fifth, as a means to participate in every activity organized by NU, including activities organized by Fatayat NU, where with this activity they can become a woman who can preserve ahlussunnah wal jamaah without leaving my nature as a woman. Sixth, Fatayat $\mathrm{NU}$ can be a forum for the next generation of ahlussunnal wal jamaah which is the legacy of the ulama and to optimize the ability of women in facing increasingly complex times.

Based on the description of the data above, it can be seen that the motivation of the women in Cilacap district to be actively involved in Fatayat NU is because they believe that Fatayat NU can be used as a place to develop themselves into women with broad religious and national views in accordance with ahlussunnah wal jama'ah without leaving her nature as a woman.

One very interesting thing is that some activists from Fatayat NU in Cilacap district work as teachers, including teacher Raudhatul Athfal (RA). This is because many Raudhatul Athfal (RA) in Cilacap district were built and organized by foundations under the auspices of NU. The Chairman of the Fatayat NU Cilacap district revealed that of the 504 RA teachers (maximum age 45 years) affiliated with NU, around $30 \%$ were Fatayat NU activists. ${ }^{14}$

Several things make Fatayat NU activists in Cilacap district are motivated to become teachers at Raudhatul Athfal (RA). First, being a teacher is a part of khidmah to NU, giving the values of the teachings of ahlussunah wal jamaah and nahdliyah to Early Childhood who later became the provision in climbing the next level of education to adulthood. Second, because through Raudhatul Athfal (RA) Fatayat NU activists were able to teach children to have morality through daily habituation activities, as well as teaching other sciences. Third, Fatayat NU activists are women who like children. To appreciate his favorite, then they pursue work as teachers at Raudhatul Athfal (RA). Fourth, children who study at Raudhatul Athfal can teach patients for Fatayat NU activists, which they think patience is the main

14 The results of an interview with Sitti Sururiyah (chairman of Fatayat NU Cilacap). 
character that must be developed in women. Fifth, there is awareness from Fatayat NU activists that the level of early childhood education is very strategic in the formation of intelligence and the formation of the character of the nation's generation.

Thus the Fatayat NU activists in Cilacap district have a real contribution in building quality human resources amid the increasingly complex life in the nation and state. One of the problems faced in the life of the nation and state is the problem of radicalism in Islam.

Fatayat NU activists who work as teachers of Raudhatul Athfal (RA) see radicalism in Islam as a very serious or acute problem. Radicalism is a serious problem that must be dealt with structurally, regularly and periodically. Radicalism is a serious problem because it can lead to intolerance, extremism (the attitude of responding to other people who are infidels) which can eventually give birth to terrorism. This seriously jeopardizes the integrity of the Unitary State of the Republic of Indonesia. ${ }^{15}$

They as teachers of Raudhatul Athfal (RA) revealed that in essence radicalism is contrary to Islam because Islam does not teach something with violence. Radical groups will do various ways so that their thoughts can be realized including by committing violence and no longer using common sense.

They explained that Islam is a religion that is rahmat an lil alamin. Islam is a religion that is friendly and accommodating to differences related to ethnicity, religion, race, and customs. Radicalism itself will harm Muslims, and the impact will be even worse when radicalism is taught in educational institutions including radical Rafahatul Athfal (RA).

Radicalism in Islamic teachings is now starting to be easily found in Cilacap district. Fatayat NU activists in Cilacap district explained that the cause of radicalism in Cilacap Muslim community was mainly due to non-political factors. For example due to lack of understanding of the teachings of ahlussunnah wal jamaah, unstable levels of faith due to conditions or socioeconomic status that are less

15 Results of interviews with Siti Mutmainah (Fatayat NU Kroya activist, RA Darussalam Kroya teacher), Sulastri (Fatayat NU North Cilacap activist, RA Masyithoh Mertasinga teacher), Nur Mahmudah (Fatayat NU Kawunganten activist, RA Abata Sarwodadi teacher), Purwaningsih (Fatayat NU activist) Wanareja, teacher of RA Ma'arif al-Falah Sidamulya), and Ida Muslihatun (activist of Fatayat NU Bantarsari, teacher of RA Ma' arif NU al-Istiqomah Bulaksari). 
supportive, low educational background, deviant religious education practices, narrow fanaticism in a religious organization, and news hoaxes.

While the causes of political factors such as the factor of dissatisfaction with the government, both the central and regional governments that triggered the desire to change the system of government. This desire or view arises because there is incitement from other parties who intentionally want to divide society.

Cases related to Islamic radicalism are also found in educational institutions, one of which is Raudhatul Athfal (RA) as an Islamic education institution that provides formal education services for early childhood. These cases befell the teacher and guardian of the students at Raudhatul Athfal.

Based on the results of data collection, it can be seen that the case of radicalism in Islamic teachings experienced by the teacher as found by the teacher who views that Pancasila does not need to be taught to children because Pancasila is contrary to Islamic law. Other cases such as the prohibition of singing national songs, not holding flag ceremonies, introducing national heroes to children. Teachers who are influenced by radicalism become closed personalities, are reluctant to associate with their disagreeable people, and consider the thoughts of other teachers who are not as wrong and distorted. ${ }^{16}$

Fatayat NU activists in Cilacap regency, the case was not just left. They approach and discuss with radical teachers so that their understanding of Islam is no longer extreme. Discussion activities are carried out formally in a family atmosphere. This method is powerful enough to change the way of thinking of radical teachers. Another effort taken to prevent the entry of radical ideas spread by teachers is to select teachers at Raudhatul Athfal (RA) by paying attention to the track record of prospective teachers both in terms of education and in terms of their organizational activities.

From the interviews, it can be seen that there are four characteristics of teachers who began to be influenced by radicalism. First, they tend to close themselves off from friendship with other

16 Results of interviews with Siti Mutmainah (Fatayat NU Kroya activist, RA Darussalam Kroya teacher), Rahajeng Asmiyanti Nurul Khotimah (Fatayat NU Kuripan activist, RA Plus Ulil Albab East Tritih), and Sulastri (Fatayat NU North Cilacap activist, RA Masyithoh Mertasinga teacher). 
teachers who do not agree with them. Second, dress with different clothing models with teachers in general. Third, forbid children from singing and dancing. Fourth, do not introduce Pancasila, national songs, and national heroes to children.

Fatayat NU activist in Cilacap district revealed that the prevention of radical understanding of teachers at Raudhatul Athfal (RA) was the main step in preventing the spread of radical notions in early childhood in the alpha generation category. The prevention of radicalism in the alpha generation was then carried out by the Fatayat NU activists of Cilacap district itself by fortifying themselves from the effects of radicalism. Efforts are made such as fostering compassion for fellow teachers without discriminating, respecting the opinions and thoughts of other teachers, increasing knowledge of Islamic teachings in the frame of ahlussunnah wal jama'ah, fortifying themselves not to be affected by hoaxes on the internet that can divide unity nation, and regular meetings that discuss issues in religion and jointly seek solutions. Then based on the results of data collection, it can be seen that there are several steps taken by the activists of Fatayat NU, Cilacap district in preventing radical understanding of the alpha generation.

First, optimizing the implementation of religious education for the alpha generation at Raudhatul Atfhal (RA). This step is done by familiarizing children to perform religious rituals such as prayer, familiarize children to read the Qur'an, familiarize children with charity, and familiarize children to pray in every activity. With these habituation activities, the child's faith will form and develop into strong. Strong formed faith from an early age will have a strong influence on the development of a child's faith in his adult life. With this strong faith, children can fortify themselves from radicalism in the present and the future.

The teacher becomes the party that facilitates the child to carry out religious ritual activities in his school in an orderly manner. From the observations it can be seen that the habits of performing religious rituals in the school environment make the display of children's behavior tend to be calm do not like fighting with his friends, the child becomes a friendly and polite figure. These characters then what will make children are protected from radicalism. 
Based on the results of research observations, it can be seen that the method used in optimizing the implementation of religious education is the habituation method. There are two types of habituation activities carried out, namely routine habituation and spontaneous habituation. Routine habituation is carried out on a scheduled basis, including habituating habit, habituation of tadarus al-Qur' an, habituation of duha prayer, habituation of Friday charity, and habituation of praying in carrying out daily activities. The activity is intended to shape the personality of an Islamic child. The personality of the Islamic child will then make the child a friendly person. While spontaneous habituation is carried out incidentally following the situations and conditions surrounding the child's activities. Spontaneous habituation activities carried out include greeting, shaking hands, smiling, apologizing, asking for help and saying thank you. These habits are also intended to form friendly characters in children. The friendly character of the child is believed by the teacher to be a character that makes children prevented from understanding radicals. ${ }^{17}$

Psychologically, optimizing the implementation of religious education for the alpha generation to prevent radical understanding influences the development of religion and morals which also influences the development of children's spiritual intelligence. Strong faith will make children have spiritual intelligence. With his spiritual intelligence, children in the present and the future will become a religious generation. Their religiousness is reflected in their attitude of love for peace.

Second, optimizing the implementation of character education for the alpha generation in Raudhatul Athfal (RA). Character education is a process of internalizing character values in the alpha generation. Internalizing these character values can be used as an effort to prevent the radical understanding of the alpha generation. Internalized values such as caring, tolerance, justice, respect for diversity, peace of mind, forgiveness, and love for the motherland, confidence, and courage to express opinions.

The internalization of character values is carried out through thematic learning activities. From the results of the author's

17 The results of observations in RA Darussalam Kroya, RA Masyithoh Mertasinga North Cilacap, and RA Ma' arif Raden Fatah Sidamulya Wanareja. 
documentation, it can be seen that the character values that are to be internalized are included in the weekly implementation of the learning plan and the implementation of daily learning plans made by the teacher. This is done to ensure that the internalization of character values can be realized in learning activities by each teacher.

Based on the results of research documentation found one theme in learning activities that lead to internalization of tolerance, namely the theme of religious holidays. The theme has 3 sub-themes, namely knowing the names of religions, recognizing religious worship, and knowing religious holidays. When the writer observes the themes and sub-themes, the teacher internalizes the tolerance value through the activity of playing picture cards and singing.

Psychologically, optimizing the implementation of character education for the alpha generation to prevent radical understanding influences emotional and social development and influences the development of emotional intelligence. With emotional intelligence children will become individuals who live full of caring, justice, compassion, tolerance, forgiveness, confidence, and openmindedness. That personality will make children in the present and the future prevented from the bad influence of radicalism.

Third, introduce nationalism to the alpha generation. This is done by utilizing artistic activities such as introducing folk songs to children, introducing national songs to children, introducing traditional musical instruments, introducing traditional clothes, and introducing regional dances. The introduction is done through learning activities and performing arts activities. With these activities, the spirit of nationalism in the alpha generation will be embedded. It is the spirit of nationalism that will be able to fortify the generation of radicalism. One interesting finding is that one of the songs taught to the alpha generation by Fatayat NU activists in Cilacap district is the song "Yaa Lal Wathan" by KH. Wahab Hasbullah. The lyrics to the song teach about nationalism and the love of the country. This is a characteristic of Raudhatul Athfal (RA) affiliated to Nahdhatul Ulama (NU).

Psychologically, efforts to prevent radical understanding by utilizing artistic activities in children can also optimize cognitive development, art development, and emotional development in 
children. Dancing activities with regional dances can also optimize the development of motor skills in early childhood.

Then the introduction of nationalism was carried out by introducing national heroes and carrying out flag ceremonies. The introduction of national heroes is not only carried out symbolically by utilizing media images but also by telling stories about the heroism of the nation's heroes in seizing independence and maintaining independence. The children were very enthusiastic to listen to these heroic stories and make children have the desire to imitate the heroes who so loved their homeland. After the children listened to the story they recounted the story of the heroism of the nation's heroes.

Psychologically, this activity can not only be used as an effort to prevent the influence of radical notions on the alpha generation but also can be used to optimize language development in children, especially to optimize listening skills and speech abilities.

Fourth, create an environment in child-friendly Raudhatul Athfal (RA). The child-friendly environment in Raudhatul Athfal (RA) was formed by Fatayat NU activists in Cilacap district who work as teachers by compiling school regulations and applying them consistently. For the sake of efforts to prevent radical understanding of the alpha generation, school regulations are compiled and implemented to reduce and even eliminate cases of violence committed between teachers and children and between children and children.

The creation of a child-friendly environment in Raudhatul Athfal (RA) is also accompanied by the creation of a child-friendly family environment. This is done by collaboration between teachers and parents in holding parenting activities. In this parenting activity, parents are provided with material and methods in educating children in the family environment and methods that can be used to create a child-friendly family environment.

Raudhatul Athfal (RA) environment and child-friendly family environment make teachers and parents gentle towards children, care for children, and do not easily punish children for solving problems. With the hospitality displayed by the teacher and parents, the children will imitate that friendliness and not be rude, hard, and narrow-minded as the characteristics of radical individuals. 
From the observations, it was found that there are two habituation activities that are applied to produce a child-friendly RA environment, namely routine habituation activities in the form of $3 \mathrm{~S}$ habituation (salam, sapa, and senyum) as well as spontaneous habituation in the form of TOMAT habituation (tolong, maaf, and terima kasih). $3 \mathrm{~S}$ habituation and TOMAT habituation make children personal friendly. The teacher accustoms the child to greeting, greeting, and giving a smile before starting to study together and when the children want to go home from school. While the TOMAT habituation is done spontaneously when the child wants to ask for help from other children and when the child has received help from other children. ${ }^{18}$

Fifth, be selective about learning materials and learning media that have the potential to bring radical understanding. This effort is carried out by reviewing student books that are intended to be distributed. If the results of the study do not find material or media that have the potential to generate radical understanding, the book can only be distributed.

The efforts of Fatayat NU activists in Cilacap district in preventing radical understanding of the alpha generation in Raudhatul Athfal (RA) must certainly be supported by the government through the Ministry of Religion of the Cilacap District Regional Office. Fatayat NU activists in Cilacap district have hopes that the government will make several efforts. First, compiling an education plan that is relevant to the challenges of the times, one of the challenges is radicalism in religion. Second, being selective in recruiting teachers, there should be no teachers who are radical because what happens is that radicalism is spread by their teachers. Third, provide training for teachers related to handling cases of radicalism in educational institutions. Fourth, giving sanctions to educational institutions that prohibit the implementation of national activities. ${ }^{19}$

18 The results of observations on RA Ma'arif NU al-Istiqomah Bulaksari Bantarsari and RA Abata Sarwodadi Kawunganten.

19 Results of interviews with Siti Mutmainah (Fatayat NU Kroya activist, RA Darussalam Kroya teacher), Sulastri (Fatayat NU North Cilacap activist, RA Masyithoh Mertasinga teacher), Nur Mahmudah (Fatayat NU Kawunganten activist, RA Abata Sarwodadi teacher), Purwaningsih (Fatayat NU activist) Wanareja, teacher RA Ma'arif al-Falah Sidamulya), Ida Muslihatun (Fatayat activist NU Bantarsari, teacher RA Ma'arif NU al-Istiqomah Bulaksari), and Sitti Sururiyah (chairman of Fatayat NU Cilacap). 
Then if you look at the steps taken by the teacher in preventing radicalism in early childhood it can be said that the most effective way to prevent radicalism is through optimizing Islamic religious education and optimizing artistic activities. Both of these efforts can activate the child's right brain. Arman Yurisaldi, a neurologist and neurologist in his research, revealed that an active and trained right brain of a child can reduce aggressive behavior in children. This means that to carry out efforts to prevent radicalism in early childhood right brain stimulation needs to be done. A child with a well-trained right brain is less likely to be affected by radical notions. ${ }^{20}$ So if the implementation of education for early childhood is done only to focus on activation of the child's left brain, then the child may become a person who is rigid and easily influenced by radical notions.

\section{CONCLUSION}

Prevention of radical understanding of the alpha generation in Raudhatul Athfal (RA) by activist Fatayat NU was carried out through seven efforts. First, by assisting teachers who are influenced by radical understanding through non-formal discussion activities in a family atmosphere. Second, fortify themselves from the negative influence of radicalism by continuing to increase knowledge and religious insights from the perspective of ahlussunnah wal jamaah. Third, optimizing the implementation of religious education for the alpha generation. Fourth, optimizing the implementation of character education for the alpha generation. Fifth, introduce nationalism to the alpha generation. Sixth, creating a Raudhatul Athfal (RA) environment and a child-friendly family environment. Seventh, selective on learning materials and learning media to make sure they do not have the potential to bring radical understanding.

The seven efforts in preventing radical understanding for the alpha generation above can be used as a guide for PAUD institutions to develop and implement a moderation program for early childhood. The moderation program aims to form the character of children who are friendly, tolerant and open-minded. When a child has these characteristics he will become a person who is protected from Islamic

20 Arman Yurisaldi, Jangan Biarkan Anak Menjadi Teroris: Tinjauan Ilmu Kedokteran Syaraf Modern, Islam Moderat, dan Budaya Jawa (Yogyakarta: Titano, 2011), 50 . 
radicalism. Based on the results of this study, the authors recommend the reader to follow up with conducting development research related to the design of Early Childhood Education curricula based on a religious character.

\section{REFERENCES}

Andrian Pratama Taher, dan Baca selengkapnya di artikel "Facebook Masih Jadi Lahan Penyebar Paham Radikalisme di Indonesia “, https://tirto.id/cA9w. "Facebook Masih Jadi Lahan Penyebar Paham Radikalisme di Indonesia Baca selengkapnya di artikel "Facebook Masih Jadi Lahan Penyebar Paham Radikalisme di Indonesia “, https://irto.id/cA9w.” Id, 4 Desember 2017. https://tirto.id/facebook-masih-jadi-lahan-penyebar-pahamradikalisme-di-indonesia-cA9w.

Arifianto, Alexander R. "Practicing What It Preaches? Understanding the Contradictions between Pluralist Theology and Religious Intolerance within Indonesia's Nahdlatul Ulama." Al-Jami'ah: Journal of Islamic Studies 55, no. 2 (15 Desember 2017): 24164. https://doi.org/10.14421/ajis.2017.552.241-264.

Arman Yurisaldi. Jangan Biarkan Anak Menjadi Teroris: Tinjauan Ilmu Kedokteran Syaraf Modern, Islam Moderat, dan Budaya Jawa. Yogyakarta: Titano, 2011.

Bagus Takwin, et.al. Studi tentang Toleransi dan Radikalisme di Indonesia: Pembelajaran dari 4 Daerah Tasikmalaya, Jogjakarta, Bojonegoro, dan Kupang. 2018 ed. Vol. 2018. Jakarta: INFID, t.t.

J. Sumardianta, dan Wahyu Kris AW. Mendidik Generasi $Z$ dan A: Marwah Era Millenial Tuah Generasi Digital,. Jakarta: Grasindo, 2018.

Jalaluddin. Psikologi Agama. Jakarta: Rajawali Press, 2015.

John W. Santrock. Masa Perkembangan Anak. Jakarta: Salemba Humanika, 2011. 
Mona Ratuliu. Digital Parenting: Tips Mengasuh Kids Zaman Now. Jakarta: Mizan Publika, 2018.

Muhammad Ridlo. "Sepotong Lirik Lagu 'Tepuk Anak Soleh' Picu Polemik di Banyumas." Com. Accesed 22 Juni 2019. https:// www.liputan6.com/regional/read/3045091/sepotong-liriklagu-tepuk-anak-soleh-picu-polemik-di-banyumas.

Qodir, Zuly. "Kaum Muda, Intoleransi, dan Radikalisme Agama." Jurnal Studi Pemuda 5, no. 1 (9 Agustus 2018): 429. https:// doi.org/10.22146/studipemudaugm.37127.

Rini Hildayani, dkk. Psikologi Perkembangan Anak. Jakarta: Universitas Terbuka, 2013.

Siti Aisyah, dkk. Perkembangan dan Konsep Dasar Pengembangan Anak Usia Dini. Jakarta: Universitas Terbuka, 2012.

Suyadi and Maulidya Ulfah. Konsep Dasar PAUD. Bandung: Rosda, 2013. 